\title{
APP-105-AM オステオポンチンの尿路結石形成に関わる機能的アミノ酸配列の同定と機能解析
}

\author{
大同病院泌尿器科"1, 名古屋市立大学大学院医学研究科腎・泌尿器科学分野2)

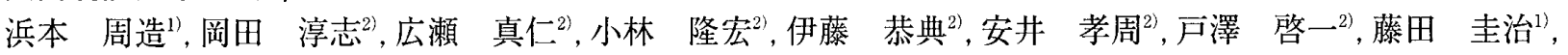 \\ 郡 健二郎 ${ }^{21}$
}

【目的】尿路結石形成にはオステオポンチン（以下 OPN）が関わっていると考えられているが、その機序は未だ不明である。私たちは、OPNが 2 つの特徽的なアミノ酸配列（1カルシウム親和性が高い2 䇢所のカルシウム結合領域、2インテグリンと結合し細胞接着に関わる Arg-Gly-Asp (RGD)配列)を有することに着目し、尿路結石形成に密接な役割を果たしていると考えた。そこで本研究では、OPNから1カルシウム結合領域 2 細胞接着領域 (RGD 配列)をそれぞれ変異・欠失させた遺伝子改変マウスを作製し、腎結晶形成に与える影響を検討した。対象と方法】カルシ ウム結合領域を欠失させた変異 $\mathrm{OPN}$ 遺伝子導入マウスと、RGD 配列を RGE 配列へ変異させた RGD 機能不全マウス、をマイクロインジェクショ ンによる遺伝子導入により作成した。それぞれのトランスジェニックマウスを継代し、OPNノックアウトマウス (OPN-KO 群) と交配させ、内 因性 OPN の発現を抑制した OPN 機能欠損マウス（以下、CaX 群、RGE 群）を作成した。 8 週齡C57BL/6 雄マウスの Wild-type マウス（WT 群)、 $\mathrm{OPN}-\mathrm{KO}$ 群、 $\mathrm{CaX}$ 群、RGE 群の 4 群（各 28 匹）に、グリオキシル酸 $(100 \mathrm{mg} / \mathrm{kg})$ を腹腔内連日投与し、投与 0.3 .6 .9 日目に腎組織を採 取した。オステオポンチン蛋白の発現は、免疫染色、ウェスタンブロッテイング法を用い評洒した。結晶形成の䛨価は、数・部位・微細構造の 3

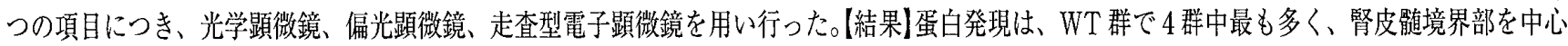
に認めた。OPN-KO 群では発現は見られず、RGE 群とCaX 群では、腎皮骮境界部に発現を認めるものの、WT群と比べ低下していた。シュウ酸 カルシウム結晶の形成量は、WT群で最も多く、ついで CaX 群で多く、RGE群と OPN-KO 群では、同程度、少量であった。結晶形成部位は、 WT 群、CaX 群、RGE 群では、腎皮䁶境界部に形成されるも、OPN-KO 群では皮質部に散在して認めた。結晶の微細構造は、RGE 群ではWT 群に類似し、結晶が整然と放射状に重なり花弁状構造を示していたが、CaX 群では直方体の結晶が秩序なく層状に連なる特徴的な形態を示した。 OPN-KO 群では、他 3 群と異なり、結晶核が小さく、砂状に集まる形態を示した。考察IOPNには、腎結晶形成に関わる2つの機能的アミノ酸 配列が存在することがわかった。カルシウム結合領域は結晶の形成過程に、細胞接着領域（RGD配列）はそれ以前の初期形成に作用するものと 考えられた。緗胞接着機能を有するRGD 配列は、尿路結石形成において、結晶が尿細管上皮に付着する段階で作用している可能性がある。

\section{APP-106-AM 腎結石形成と消失に関わる腎マクロファージの結晶領食メカニズムの解明}

\section{名古屋市立大学大学院医学研究科腎・泌尿器科学}

岡田 淳志, 新美 和寛, 小林 隆宏, 廣瀬 泰彦, 宇佐美 雅之, 浜本 周造, 広瀬 真仁, 伊藤 恭典, 安井 孝周, 戸澤 啓一,郡 健二郎

目的：これまでに私たちは、マウスにおいて腎結石を形成するモデルを確立し、その研究過程において腎尿細管内に形成されたシュウ酸カルシウム結石が 経時的に消失する現象を見いだした。さらにマイクロアレイを用いた解析によって、結石の形成・消失には、結石マトリックス蛋白であるオステオポンチ ンを介した腎マクロファージによる結晶の領食が関与方る可能性を示唆した。以上の結果より、結石形成には正常な㹂蓇の持つ結石処理能力が関与してお り、この能力の低下が尿路結石の堌大に関与寸る」とい仮説を提唱した。尿路結石の形成機序は、マクロファージの脂質貪食を介した動脈硬化形成機序と 類似すると考えられていることからも、腎マクロファージの機能制御が結石予防に槃がるものと期待している。本研究では、結石形成および消失における

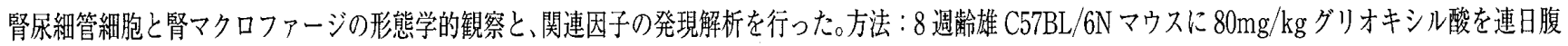

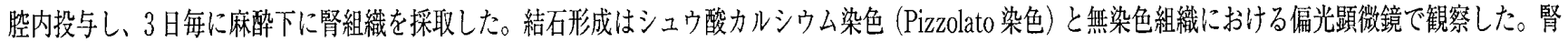
マクロファージは、F4/80免疫染色により観察するとともに、透過型電視影微鏡 (TEM)により超微細構造の観察を行った。結石モデルマウスのマイクロ アレイ解析結果より抽出された関連遺伝子として、結石マトリックスの主成分であるとともにマクロファージ走化因子である osteopontin (OPN)，ケモカ インである monocytes chemoattractant protein 1 (MCP-1)，マクロファージによる食食の標的であるとともに結石関連遺伝子である fibronectin (FN), OPN と FN の受容体であり、マクロファージ表面に発現するCD44, マクロファージの活性化の指嘌となるMHC-class II、これら発現を免没染色と定量 PCRにより確認し、結晶形成部位とマクロファージの局在と活性化の状態について評価した。結果：結石は、グリオキシル酸投与 3 日目より出現し、6 日目まで増加する。その後減少して、15 日目までに消失した。OPN，MCP-1,FNは、投与 3 日目から発現増加した。経侍的にマクロファージか腎間質に 増加し、特に結石形成している屎絊管周困に集簇した。結石の存在部位に一致して、CD44 およびMHC-class II の発現を認め、尿細管に移行したマクロ ファージによるCD44を介した領食と、マクロファージの活性化に伴う抗原提示を認めた。またTEMでは多核巨緗胞が結晶を領食している像を認めた。 考察: 腎結晶形成・沈着によって誘導された腎尿細管細胞の OPN, MCP-1, FN 発現により、腎に遊走したマクロファージは、CD44を介して結晶を貪食寸 るものと考えられた。このようなマクロファージによる領食を介した結晶处理能力が結石形成に対する自己防御ともいえる作用を持つものと推察された。 